
License. Which Permits unrestricted use, distrubution, and reproduction in any medium, provided the original work is properly cited

\title{
Orientasi Filosofis Hakim Pengadilan Agama Dalam Menyelesaikan Sengketa Ekonomi Syariah
}

\author{
Zaidah Nur Rosidah dan Lego Karjoko \\ Fakultas Syariah IAIN Surakarta dan Fakultas Hukum UNS Surakarta \\ Jawa Tengah Indonesia \\ Jln. Pandawa No. 23, Dusun IV Pucangan Kartasura Sukoharjo Jawa Tengah \\ Indonesia 57168 \\ Jln. Ir Sutami No. 36A Jebres Surakarta Jawa Tengah Indonesia 57126 \\ zaidahnurr@yahoo.com dan legokarjoko@staff.uns.ac.id
}

Received: 26 Juli 2020; Accepted: 18 November 2020; Published: 16 Maret 2021

DOI: 10.20885/iustum.vol28.iss1.art8

\begin{abstract}
The purpose of this study is to determine the philosophical basis in the legal finding school of thoughts used by religious court judges and their orientation in resolving sharia economic disputes. The research problem is answered by using a normative method with a case and conceptual approach. The results of the research and discussion conclude that first, sharia economic dispute resolution has a philosophical foundation from the values of Pancasila, especially the first, second and fifth principles. Second, there are two different orientations of religious court judges in deciding sharia economic disputes, namely legism oriented and begriffjurisprudenz orientation. Amongst the various decisions, there are judges that are still oriented towards legism, namely deciding disputes based on existing positive laws, based on the Civil Code (KUHPer) even though the dispute is a sharia economic dispute. There are also many judges who have an orientation to begriffurisprudenz, in this case the judge uses the basis of Islamic law, namely the Al Quran, Hadith and the Fatwa of the National Sharia Council (DSN) of the Indonesian Ulama Council (MUI) and the Compilation of Sharia Economic Law (KHES) in their decisions in addition to using the Civil Code (positive law).
\end{abstract}

Key Words: Philosophical orientations; religious court; sharia economic disputes

\section{Abstrak}

Tujuan penelitian ini adalah untuk mengetahui landasan filosofis dalam mazhab penemuan hukum yang digunakan oleh hakim pengadilan agama serta orientasinya di dalam menyelesaikan sengketa ekonomi syariah. Permasalahan penelitian dijawab dengan menggunakan metode normatif dengan pendekatan kasus dan konseptual. Hasil penelitian dan pembahasan menyimpulkan pertama, penyelesaian sengketa ekonomi syariah memiliki landasan filosofis dari nilai-nilai Pancasila khususnya sila pertama, kedua dan kelima. Kedua, ada dua ragam orientasi hakim pengadilan agama dalam memutuskan sengketa ekonomi syariah yaitu berorientasi legisme dan berorientasi begriffurisprudenz. Dari berbagai putusan, ada hakim masih berorientasi pada legisme, yaitu memutuskan sengketa berdasarkan hukum positif yang ada yaitu mendasarkan pada Kitab Undang-Undang Hukum Perdata (KUHPer) meskipun sengketanya adalah sengketa ekonomi syariah. Banyak pula hakim yang berorentasi pada begriffurisprudenz, dalam hal ini hakim menggunakan dasar hukum Islam yaitu Al Quran dan Hadits serta Fatwa Dewan Syariah Nasional (DSN) Majelis Ulama Indonesia (MUI) dan Kompilasi Hukum Ekonomi Syariah (KHES) dalam putusannya selain menggunakan KUHPerdata (hukum positif).

Kata-kata Kunci: Pengadilan Agama; orientasi filosofis; sengketa ekonomi syariah 


\section{Pendahuluan}

Perkembangan ekonomi syariah di Indonesia saat ini cukup menggembirakan. Tidak saja perbankan yang tumbuh pesat, akan tetapi berbagai lembaga keuangan syariah lainnya juga sudah berkembang seperti asuransi syariah dan pegadaian syariah. Menurut data dari Otoritas Jasa Keuangan pada April 2018 terdapat 13 Bank Umum Syariah, 21 Unit Usaha Syariah dan 168 Bank Pembiayaan Rakyat Syariah (BPRS). Sedangkan perusahaan asuransi syariah berjumlah 13 perusahaan dan Unit Usaha Syariah pada perusahaan asuransi berjumlah 50, lembaga pembiayaan syariah sebanyak 7 dan unit usaha syariahnya berjumlah 40, Dana Pensiun Syariah sebanyak 1, Lembaga Keuangan Khusus Syariah sebanyak 4, dan Lembaga Keuangan Mikro Syariah sebanyak $42 .{ }^{1}$

Setiap Lembaga Keuangan Syariah (LKS), baik perbankan ataupun non bank dalam menjalankan kegiatan operasionalnya harus sejalan dan sesuai dengan prinsip-prinsip syariah. Penerapan prinsip-prinsip syariah juga harus mengacu pada etika bisnis secara Islami yaitu berlandaskan pada Al-Qur'an dan Assunnah. Tidak hanya itu, etika bisnis dalam Islam juga mengacu pada tauhid, keseimbangan, kehendak bebas, pertanggungjawaban dan ikhsan. ${ }^{2}$

Dengan pesatnya pertumbuhan lembaga keuangan syariah tersebut maka perlu mendapat dukungan perangkat hukum yang memadai agar persoalan yang timbul dari kegiatan yang beroperasi secara syariah tersebut memperoleh kepastian hukum. Aspek yang perlu mendapatkan perhatian penting adalah penyelesaian sengketa ekonomi syariah. Dalam hal sengketa terjadi antar pihakpihak dalam kegiatan bisnis yang berdasarkan syariah maka penyelesaiannya dikembalikan kepada prinsip dasarnya yaitu dengan mekanisme penyelesaian yang berdasarkan syariah.

Terjadinya sengketa dalam menjalankan bisnis akan selalu dapat dimungkinkan terjadi, meskipun sengketa itu tidak dikehendaki oleh para pihak. Sebenarnya terjadinya sengketa itu mencerminkan watak dasar manusia yang memiliki kemauan yang tidak seragam. Cara yang digunakan oleh masyarakat di

1 Abdul Rasyid, Perkembangan Lembaga Perbankan Dan Keuangan Syariah Di Indonesia, https://businesslaw.binus.ac.id/2018/07/03/perkembangan-lembaga-perbankan-dan-keuangan-syariah-di-indonesia/, diakses 25 Juni 2020.

2 https://www.hestanto.web.id/lembaga-keuangan-syariah-lks/, diakses 25 Agustus 2020. 
dalam menyelesaikan sengketa dapat dilakukan dengan berbagai cara. Masingmasing pendekatan menggunakan paradigma yang berbeda sesuai dengan tujuan, budaya serta nilai yang diyakini oleh para pihak. Ada dua pendekatan yang digunakan dalam menyelesaikan sengketa yaitu pendekatan litigasi dan non litigasi. Pendekatan litigasi dengan menggunakan perlawanan dan menggunakan paksaan dalam pengelolaan sengketa dengan menghasilkan keputusan menang dan kalah bagi pihak yang bersengketa. Sedangkan pendekatan kedua menggunakan pendekatan non litigasi. Pada pendekatan non litigasi yang lebih diutamakan adalah perdamaian dan berupaya untuk mempertemukan kepantingan para pihak yang bersengketa dengan harapan bahwa akan diperoleh penyelesaian sengketa ke arah win-win solution. ${ }^{3}$

Pada kenyataannya, banyak akad-akad syariah baik di berbagai lembaga keuangan baik bank syariah maupun di lembaga keuangan non bank yang di dalam akadnya menentukan penyelesaian sengketa melalui pengadilan agama dibandingkan memilih melalui Badan Arbitrase Syariah Nasional (Basyarnas). Pilihan penyelesaian sengketa melalui litigasi tersebut didasarkan pada bahwa apabila penyelesaian sengketa dilakukan melalui pengadilan maka pihak yang tidak puas masih ada kesempatan untuk melakukan upaya hukum lagi, sementara jika diselesaikan melalui Basyarnas bersifat final. ${ }^{4}$

Berdasarkan UU Nomor 3 Tahun 2006 tentang perubahan pertama atas UU Nomor 7 Tahun 1989 tentang Peradilan Agama, pada Pasal 49 disebutkan bahwa Pengadilan agama bertugas dan berwenang memeriksa, memutus, dan menyelesaikan perkara di tingkat pertama antara orang-orang yang beragama Islam di bidang: (a) perkawinan; (b) waris; (c) wasiat; (d) hibah; (e) wakaf; (f) .zakat; (g) infaq; (h) shadaqah; dan (i) ekonomi syari'ah. Kewenangan penyelesaian perkara sengketa ekonomi syariah sebelumnya tidak diatur dalam UU Nomor 7 Tahun 1989. Kewenangan pengadilan agama dalam menyelesaikan sengketa ekonomi syariah tersebut tidak hanya dibatasi untuk menyelesaikan di bidang perbankan saja tetapi juga di bidang ekonomi syariah lainnya.

3 Adi Sulistiyono, Mengembangkan Paradigma Non-Litigasi di Indonesia, Sebelas Maret University Press, Surakarta, 2006, hlm. 2-5.

${ }^{4}$ Zaidah Nur Rosiidah, dkk, Aspek Keadilan Penyelesaian Sengketa Ekonomi Syariah Melalui Pengadilan Agama, Laporan Penelitian, Surakarta, LPPM IAIN Surakarta, 2016, hlm. 67. 
Kewenangan pengadilan agama untuk menyelesaikan sengketa ekonomi syariah ini juga diatur di dalam Pasal 55 ayat (1) UU Perbankan Syariah. Pasal tersebut dinyatakan bahwa penyelesaian sengketa perbankan syariah dilakukan oleh pengadilan di dalam lingkungan Peradilan Agama.

Kompetensi absolut pengadilan agama dalam memeriksa dan memutus sengketa ekonomi syariah menjadi diperkuat setelah putusan Mahkamah Konstitusi Nomor 93/PUU-X/2012 yang mengabulkan permohonan Dadang Ahmad. Di dalam putusan Mahakamah Konstitusi tersebut menyatakan bahwa penjelasan Pasal 55 ayat (2) UU Perbankan Syariah bertentangan dengan UUD NRI Tahun 1945 dan tidak mempunyai kekuatan hukum mengikat. Pertimbangan Mahkamah Konstitusi memutuskan permohonan tersebut adalah bahwa penjelasan Pasal 55 ayat (2) UU Perbankan Syariah yang memberikan pilihan tempat dalam menyelesaikan sengketa ekonomi syariah dapat menyebabkan tumpang tindihnya kewenangan untuk mengadili antara pengadilan agama dan pengadilan negeri. Sementara itu apabila merujuk pada UU Nomor 3 Tahun 2006 tentang Perubahan atas UU Nomor 7 Tahun 1989 tentang Peradilan Agama dengan jelas di Pasal 49 huruf i menyatakan salah satu kewenangan pengadilan agama adalah memeriksa, memutus dan menyelesaikan di tingkat pertama perkara ekonomi syariah. Dengan demikian, maka kewenangan absolut penyelesaian sengketa ekonomi syariah berada di bawah lingkungan peradilan agama.

Perkara ekonomi syariah yang masuk ke pengadilan agama terus meningkat. Berdasarkan direktori putusan Mahkamah Agung RI, ${ }^{5}$ sampai dengan Juni 2020 ini perkara yang telah diputus oleh pengadilan agama seluruh Indonesia sebanyak kurang lebih 1020 perkara. Perkara tersebut belum termasuk sisa perkara yang belum berkekuatan hukum tetap karena masih dalam proses upaya hukum. Perkara-perkara yang masuk ke pengadilan agama didominasi perkara perdata umum yaitu nasabah melakukan wanprestasi atau nasabah melakukan perlawanan karena benda jaminan yang akan dilelang oleh pihak

5 https://putusan3.mahkamahagung.go.id/direktori/kategori/jenis/ekonomi-syari-ah-1.html, diakses 25 Juni 2020. 
bank, sedangkan terjadinya sengketa yang disebabkan karena tidak dilaksanakannya atau tidak dipatuhinya prinsip syariah tidak dominan. ${ }^{6}$

Kompetensi absolut pengadilan agama dalam memeriksa dan memutus perkara ekonomi syariah tidak terlepas dari sifat perkara ekonomi syariah yang didasarkan pada akadnya yang timbul berdasarkan prinsip syariah. Prinsip syariah sebagaimana yang disebutkan di dalam UU Perbankan Syariah Pasal 1 butir 12 yaitu prinsip hukum Islam di dalam kegiatan perbankan berdasarkan fatwa yang dikeluarkan oleh lembaga yang memiliki kewenangan dalam penetapan fatwa di bidang syariah. Di Indonesia lembaga tersebut adalah Majelis Ulama Indonesia.

Penerapan prinsip-prinsip syariah dalam bermuamalah mengacu pada fatwa DSN MUI yang telah menentukan prinsip-prinsip syariah dalam masingmasing bentuk akad. MUI telah mengeluarkan himpunan fatwa tentang keuangan syariah, ekonomi syariah dan bisnis syariah. Sehingga setiap produk yang dikeluarkan oleh lembaga keuangan syariah harus mengacu kepada fatwa DSN MUI sebagai sumber hukumnya. Di dalam fatwa tersebut sudah ditentukan prosedur setiap produk. Sehingga jika terjadi sengketa penyelesaiannya juga harus dikembalikan sesuai dengan prinsip syariah.

Sebagaimana ketentuan Pasal 24 ayat (1) UUD NRI Tahun 1945 disebutkan, bahwa kekuasaan kehakiman merupakan kekuasaan yang merdeka, untuk menyelenggarakan peradilan guna menegakkan hukum dan keadilan. Selanjutnya, di dalam Pasal 2 ayat (2) UU Kekuasaan Kehakiman disebutkan bahwa peradilan negara menerapkan dan menegakkan hukum dan keadilan berdasarkan Pancasila. Pasal 5 ayat (2) disebutkan bahwa hakim dan hakim konstitusi wajib menggali, mengikuti, dan memahami nilai-nilai hukum dan rasa keadilan yang hidup dalam masyarakat. Oleh karena, itu hakim penngadilan agama sebagai salah satu pelaksana kekuasaan kehakiman harus mengacu kepada Pancasila sebagai dasar filosofis di dalam putusannya. Menegakkan hukum dan keadilan berdasarkan Pancasila dapat dipahami sebagai dasar bagi

${ }^{6}$ Amran Suadi, Penyelesaian Sengketa Ekonomi Syariah Penemuan dan Kaidah Hukum, Jakarta, Prenada media Group, 2018, hlm. 32-33. 
para hakim dalam menyelesaikan perkara yang diajukan kepadanya harus mengacu pada nilai-nilai yang terkandung di dalam Pancasila.

Hakim memutuskan siapa yang menang dan yang kalah berdasarkan bukti yang kuat. Pihak yang lebih kuat pembuktiannya itulah pihak yang menang di dalam sengketa. Menurut para hakim, alat bukti yang digunakan oleh bank jauh lebih lengkap dan kuat dibandingkan alat bukti nasabah. Bank syariah lebih memilih penyelesaian sengketa ke pengadilan agama dibandingkan melalui lembaga non litigasi seperti Basyarnas. Penyelesaian melalui pengadilan masih dimungkinkan untuk melakukan upaya hukum. Hal ini menunjukkan bahwa budaya hukum bank syariah lebih memilih kepada penyelesaian litigasi dibandingkan non litigasi. ${ }^{7}$

Penelitian ini bertujuan untuk menemukan ragam orientasi hakim pengadilan agama dalam menyelesaikan perkara sengketa ekonomi syariah. Banyaknya perkara yang disengketakan didominasi perkara perdata umum maka menarik untuk dikaji dasar pertimbangan hakim dalam memutuskan sengketa tersebut.

\section{Rumusan Masalah}

Berdasarkan pada uraian di atas, yang menjadi permasalahan dalam penelitian ini, sebagai berikut. Pertama, bagaimana penjabaran filsafat Pancasila di dalam mazhab penemuan hukum? Kedua, apakah orientasi filosofis hakim pengadilan agama di dalam menyelesaikan sengketa ekonomi syariah sudah sesuai dengan filsafat Pancasila?

\section{Tujuan Penelitian}

Penelitian ini bertujuan untuk mengetahui penjabaran filsafat Pancasila di dalam mazhab penemuan hukum dan orientasi filosofis hakim pengadilan agama dalam menyelesaikan sengketa ekonomi syariah.

\section{Metode Penelitian}

Jenis penelitian ini adalah penelitiah hukum normatif yaitu untuk memberikan preskripsi orientasi filososfis hakim pengadilan agama dalam menemukan hukum penyelesiaan sengketa ekonomi syariah. Metode pendekatan

\footnotetext{
7 Zaidah Nur Rosidah, dkk, Aspek Keadilan Penyelesaian Sengketa Bisnis Syariah melalui Pengadilan Agama, Laporan Penelitian, IAIN Surakarta, Surakarta, 2016, hlm. 70
} 
yang digunakan adalah pendekatan kasus dan konseptual. Teknik pengumpulan data dilakukan dengan studi pustaka. Teknik analisa data dengan menggunakan silogisme diduksi dan interpretasi. Sebagai premis mayor adalah filsafat Pancasila dan ajaran penemuan hukum, sedangkan premis minornya adalah rasio decidendi putusan hakim pengadilan agama di dalam meyelesaikan sengketa ekonomi syariah.

\section{Hasil Penelitian dan Pembahasan}

\section{Penjabaran Filsafat Pancasila dalam Mazhab Penemuan Hukum}

Pancasila sebagai ideologi negara yang merupakan kesepakatan luhur para pendiri bangsa Indonesia tidak dapat digantikan. Pancasila merupakan cita hukum yang menjadi bintang pemandu dan merupakan sumber dari segala sumber hukum. Untuk membentuk segala peraturan perundang-undangan di Indonesia harus mengacu pada nilai-nilai yang terkandung di dalam Pancasila. Sehingga Pancasila merupakan dasar filosofis dalam pembentukan maupun di dalam penegakan hukum.

Menurut Bernard Arief Sidharta, nilai-nilai yang terkadung di dalam Pancasila jika dipahami dengan baik maka akan memudahkan di dalam penjabarannya ke dalam perangkat norma yang dibuat dan menjaga konsistensinya di dalam penegakannya. Dalam penyusunan tata hukum Indonesia seyogyanya mengacu pada asas dan kaidah nilai-nilai yang terkandung di dalam Pancasila. Sejalan dengan itu, ilmu hukum yang mempelajari tatanan hukum sebagai sarana intelektual untuk memahami dan menyelenggarakan tatanan hukum tersebut, dalam pengembanannya seyogianya pula bertumpu dan mengacu pada nilai-nilai Pancasila. ${ }^{8}$

Menurut Notonegoro, Pancasila sebagai sistem filsafat menunjukkan adanya suatu hakikat makna yang bertingkat di dalam kelima sila-silanya dan membentuk piramida. Adapun jabarannya sebagai berikut. ${ }^{9}$

\footnotetext{
${ }^{8}$ Lego Karjoko, Pembadanan Asas Fungsi Sosial Hak Guna Usaha dalam Pengaturan Perkebunan yang Mensejahterakan rakyat, Disertasi, Pascasarjana UNS, Surakarta, 2017, hlm. 31

${ }^{9}$ Kaelan, Filsafat Pancasila Pandangan Hidup Bangsa Indonesia, Paradigma, Yogyakarta, 2002, hlm. 74-77
} 
Sila Ketuhanan Yang Maha Esa mendasari dan menjiwasi sila-sila lainnya yaitu sila kedua, ketiga, keempat dan kelima. Hal tersebut berdasarkan hakikat pendukung pokok dari negara adalah manusia. Negara terbentuk karena kesepakatan manusia yang hidup di masyarakat. Manusia adalah makhluk ciptaan Tuhan Yang Maha Esa, sehingga adanya manusia adalah karena kehendak tuhan sebagai kausa prima.

Sila kemanusiaan yang adil dan beradab didasari dan dijiwai oleh sila pertama. Sila kedua juga mendasari dan menjiwai sila ketiga, keempat dan kelima. Hal ini pada hakekatnya mengandung makna bahwa salah satu unsur pokok adanya negara adalah rakyat. Rakyat merupakan kumpulan dari individuindividu yang hidup di masyarakat yang menghendaki adanya negara agar tujuan bersama dapat tercapai. Tujuan hidup bersama dalam suatu negara adalah untuk mencapai keadilan sosial.

Sila persatuan Indonesia didasari dan dijiwai oleh sila pertama dan kedua serta sila ketiga ini mendasari dan menjiwai sila keempat dan kelima. Hakikat sila persautan Indonesia merupakan perwujudan dari suatu persekutuan hidup manusia dalam suatu negara. Manusia yang merupakan rakyat adalah unsur pokok terbentuknya negara. Hakikat manusia adalah makhluk tuhan sehingga sila persatuan ini didasari dan dijiwai oleh adanya persatuan individu yang merupakan makhluk tuhan yang hidup bersama di dalam masyarakat untuk membentuk negara karena disatukan oleh persamaan kepentingan untuk mencapai tujuan bersama.

Sila kerakyatan yang dipimpin oleh hikmat kebijaksanaan dalam permusyawaratan perwakilan didasari dan dijiwai sila pertama, kedua dan ketiga serta menadasari dan menjiwai sila kelima. Rakyat yang hakikatnya adalah manusia yang merupakan makhluk ciptaan tuhan disatukan dalam suatu wilayah sebagai bagian dari individu yang hidup bersama dalam suatu negara. Hakikat dari terbentuknya negara yang merupakan persatuan individu-individu tersebut bertujuan untuk terwujudnya keadilan sosial untuk kepentingan bersama.

Sila keadilan sosial didasari dan dijiwai oleh sila pertama, kedua, ketiga dan keempat. Tujuan terbentuknya negara adalah untuk mencapai keadilan bersama yaitu keadilan sosial. Manusia sebagai makhluk tuhan yang diciptakan untuk 
hidup bermasyarakat hakikatnya adalah makhluk sosial yang membutuhkan keberadaan manusia yang lain. Sebagai bagian dari individu yang hidup di dalam masyarakat maka kemanusiaan manusia harus berbuat adil baik terhadap diri sendiri, terhadap sesama manusia maupun adil terhadap tuhannya. Sila keadilan sosial bagi seluruh rakyat Indonesia bermakna pokok adalah keadilan. Sila kelima ini agak berbeda dengan sila lainnya karena sila kelima didasari dan dijiwai oleh seluruh sila sebelumnya yaitu sila pertama, kedua, ketiga dan keempat. Keadilan sosial merupakan tujuan dari keempat sila lainnya.

Pancasila seyogyanya dijadikan dasar oleh hakim dalam melakukan penemuan hukum. Prinsip dasar dalam putusan pengadilan adalah demi keadilan berdasarkan Ketuhanan Yang Maha Esa. Penemuan hukum yang dilakukan oleh hakim pada dasarnya dapat diartikan penerapan peraturan yang sifatnya abstrak ke dalam peristiwa yang konkrit. Hakim harus memecahkan atau menyelesaikan peristiwa konkrit dan untuk itu hakim harus tahu dan mencari atau menemukan hukumnya untuk diterapkan pada kasusnya. ${ }^{10}$

Dalam rangka penemuan hukum itulah maka orientasi hakim dipengaruhi oleh dasar filosofis yang berpengaruh kepada masing-masing individu hakim. Untuk itu maka dalam rangka penemuan hukum, dasar filosofis Pancasila merupakan bintang pemandu yang memuat asas yang dapat digunakan oleh hakim dalam rangka mengambil keputusan. Sila-sila yang terkadung di dalam Pancasila merupakan satu kesatuan. Antara sila pertama sampai sila kelima mengandung makna yang sangat luas dan paling dasar. Sehingga dalam rangka penemuan hukum itulah hakim dapat menggunakan dasar filosofis Pancasila sebagai bintang pemandunya.

Sila-sila yang terkait dengan penyelesaian sengketa ekonomi syariah adalah sila pertama, kedua dan kelima. Sila pertama, kedua dan kelima Pancasila diderivasi ke dalam aliran penemuan hukum begriffsjurusprudenz dan interessenjurisprudensz. Dalam aliran begriffsjurispudenz, ketidakmampuan pembentuk undang-undang meremajakan undang-undang pada waktunya merupakan alasan untuk memberi peran aktif kepada hakim. Hakim diharapkan

${ }^{10}$ Sudikno Mertokusumo, Penemuan Hukum Suatu Pengantar, Lyberti, Yogyakarta, 2009, hlm. 56. 
dapat menyesuaikan undang-undang dengan keadaan baru. Dengan demikian kebiasaan atua nilai-nilai yang hidup mendapat perannya lagi sebagai sumber hukum. Bregriffsjurisprudenz memberikan kebebasan kepada hakim dari pada legisme. Hakim tidak perlu terikat pada bunyi undang-undang, tetapi mengambil agumentasinya dari peraturan hukum yang tersirat dalam undang-undang. ${ }^{11}$

Penemuan hukum interessjurisprudenz sebagai reaksi atas penemuan hukum begriffsjurisprudenz. Menurut interessjuridprudenz, hukum merupakan akibat dari pertentangan-pertentangan kepentingan yang berlawanan dan berbenturan satu sama lain. Aliran ini berpendapat bahwa hakim tidak boleh hanya melihat peraturan hukum sebagai formal-logis belaka, tetapi juga harus melihat hukum dari tujuannya. ${ }^{12}$ Hukum bertujuan untuk melindungi, memuaskan atau memenuhi kepentingan atau keutuhan hidup yang nyata, dalam putusannya hakim harus bertanya kepentingan manakah yang diatur atau dimaksudkan oleh pembentuk undang-undang. ${ }^{13}$

Aliran penemuan hukum legisme berpendapat bahwa semua hukum itu berasal dari kehendak penguasa tertinggi dalam hal ini pembentuk undangundang. Hanya undang-undanglah yang mdapat menjadi sumber hukum. Undang-undang merupakan satu-satunya sumber hukum yang dianggap cukup jelas dan lengkap yang berisi semua jawaban terhadap semua persoalan hukum, sehingga hakim hanya berkewajiban menerapkan peraturan hukum pada peristiwa konkritnya melalui penafsiran gramatikal. ${ }^{14}$

Keharusan memuat dasar pertimbangan dengan mengambil UU sebagai sumber utama merupakan mazhab hukum Eropa Kontinental, sedangkan keharusan memuat hukum yang tidak tertulis merupakan ciri mazhab hukum anglo saxon, sementara di dalam UU Kekuasaan kehakiman menggabungkan keduanya yaitu selain menggunakan hukum tertulis, hakim wajib menggali, memahami dan mengikuti nilai yang hidup di dalam masyarakat. Dengan demikian sistem hukum yang dianut di Indonesia adalah merupakan perpaduan antara kedua sistem hukum tersebut. Hakim dapat memutuskan berbeda dengan

${ }^{11}$ Ibid., hlm. 98

12 Ibid., hlm. 99

13 Ibid., hlm. 100.

14 Ibid., hlm. 94-95. 
peraturan yang tertulis jika ada alasan yang kuat untuk mempertimbangkan berbagai aspek hukum termasuk menyimpang dari ketentuan normatif. ${ }^{15}$

Pada prinsipnya penyelesaian sengketa ekonomi syariah selain berorientasi secara filosofis terhadap sila-sila Pancasila sebagaimana disebutkan di atas, juga mendapatkan jaminan di dalam UUD 1945. Sebagaimana Pasal 29 UUD NRI Tahun 1945 bahwa hak kebebasan beragama dan menjalankan ibadah sesuai dengan keyakinannya termasuk hak asasi yang dijamin oleh konstitusi. Penerapan prinsip syariah merupakan hak spiritual warga negara khususnya yang beragama Islam. Hal ini diperkuat dengan Pasal 28 E yang menyatakan bahwa setiap orang bebas untuk melaksanakan agama dan beribadah sesuai dengan agamanya. Serta Pasal 28 I ayat (1) bahwa menjalankan agama merupakan bagian dari hak asasi manusia dan untuk mempertahankan dalam keadaan apapun. Sementara ayat (4) bahwa perlindungan, pemajuan dan penegakan hak asasi manusia merupakan tanggung jawab negara. ${ }^{16}$ Dalam hal penyelesaian sengketa ekonomi syariah pelaksanaan penegakannya dilakukan oleh pengadilan yang berada di bawah lingkungan peradilan agama.

\section{Orientasi Filosofis Hakim Pengadilan Agama dalam Menyelesaikan Sengketa Ekonomi Syariah}

Prinsip syariah sebagaimana yang menjadi tuntutan semua lembaga yang menggunakan label syariah merupakan suatu keniscayaan. Operasional lembaga keuangan syariah tidak hanya dituntut untuk mencari keuntungan dalam transaksi yang dibuatnya akan tetapi juga harus memperhatikan prinsip-prinsip syariah. Kepatuhan syariah menjadi sangat penting dalam pengaturan bank-bank syariah. Lembaga yang memiliki peran penting untuk mengawasi operasional lembaga keuangan syariah terhadap kepatuhan prinsip syariah adalah Dewan Syariah Nasional (DSN) Majelis Ulama Indonesia (MUI). Sebagaimana dalam UU Perbankan Syariah yang memberikan kewenangan kepada DSN MUI untuk

${ }^{15}$ Achmad Arief Budiman, Penemuan Hukum Dalam Putusan Mahkamah Agung Dan Relevansinya Bagi Pengembangan Hukum Islam Indonesia, Al-Abkam Jurnal Pemikiran Hukum Islam, Volume 24, Nomor 1, April 2014, hlm. 13

16 Ro'fah Setyowati, Indah Purbasari, Encik Muhammad Fauzan, Consumers Spiritual Rights in the Islamic Banking Dispute Out of Court Settlement in Indonesia dalam Journal of Social Studies Education Research, 2018:9(4), hlm. 338. 
menerbitkan fatwa kesesuaian syariah dengan produk bank. Bahkan untuk ketaatan operasional pada setiap bank harus memiliki Dewan Pengawas Syariah. ${ }^{17}$ Selain fatwa MUI yang merupakan konversi dan pengejawanatahan Al Quran, Al-hadis serta Ijtihad Fuqaha, ketaatan dan kepatuhan lembaga syariah juga harus mengacu kepada Peraturan Mahkamah Agung Nomor 02 Tahun 2008 tentang Kompilasi Hukum Ekonomi Syariah (KHES) serta sumber hukum lainnya yang berlaku. ${ }^{18}$

Lahirnya Putusan Mahkamah Konstitusi Nomor No 93/PUU-X/20012, secara yuridis telah memberikan kepastian hukum tentang kewenangan pengadilan agama dalam menyelesaikan sengketa ekonomi syariah. Dalam putusan Mahkamah Konstitusi tersebut, Pasal 55 ayat (2) UU Perbankan Syariah tidak mempunyai kekuatan hukum mengikat. Sebagaimana dalam Pasal 10 ayat (1) Mahkamah Konstitusi berwenang mengadili pada tingkat pertama dan terakhir yang putusannya bersifat final. Sehingga secara normatif penyelesaian sengketa ekonomis syariah merupakan kewenangan absolut pengadilan agama.

Menurut Abdul Manan, tugas penemuan hukum terhadap suatu perkara yang sedang diperiksa oleh hakim merupakan suatu hal yang paling sulit untuk dilaksanakan. Meskipun para hakim dianggap tahu hukum (ius curia novit), sebenarnya para hakim itu tidak mengetahui semua hukum, sebab hukum itu berbagai macam ragamnya, ada yang tertulis dan ada yang tidak tertulis. Sebagai penegak hukum hakim wajib menggali, mengikuti dan memahami nilai hukum yang hidup dalam masyarakat. 19

Perkara yang masuk ke pengadilan agama dalam gugatan sengketa ekonomi syariah pada umumnya terjadi karena wanprestasi, perbuatan melawan hukum dan perlawanan sita jaminan. Apabila seseorang atau badan hukum telah melakukan akad syariah dengan pihak lain, maka antara pihak tersebut telah terjalinnya perikatan. Oleh karena itu, menurut hukum perdata kesepakatan yang telah disetujui para pihak tersebut akan mengikat sebagai undang-undang bagi mereka yang membuatnya. Dengan demikian, terjadinya suatu sengketa ekonomi

\footnotetext{
17 https://www.ojk.go.id/id/kanal/syariah/tentang-syariah/Pages/PBS-dan-Kelembagaan.aspx, diakses 25 Agustus 2020.

${ }_{18}$ Oyo S Mukhlas, Dual Banking System \& Penyelesaian Sengekta Ekonomi Syariah, Refika Aditama, Bandung, 2019, hlm. 5

${ }_{19}$ Amran Suadi, Penyelesaian Sengketa Ekonomi Syariah, Penemuan..., hlm. 64.
} 
syariah disebabkan oleh dua pihak yang melakukan akad dengan prinisp syariah yang salah satu pihak melakukan wanprestasi atau melakukan perbuatan melawan hukum sehingga mengakibatkan pihak yang lainnya merasa dirugikan. ${ }^{20}$

Dalam putusan terhadap gugatan sengketa ekonomi syariah, ada dua ragam orientasi hakim pengadilan agama dalam memutus dan menyelesaikan sengketa. Kedua ragam tersebut yaitu hakim yang berorientasi pada penemuan hukum yang legisme dan hakim yang berorientasi pada penemuan hukum begriffsjurisprudenz. Hakim pengadilan agama yang hanya menggunakan dasar pertimbangan hukum yang tertulis saja berorientasi pada legisme, sedangkah dasar pertimbangan hakim yang menggunakan hukum tertulis dan hukum yang tidak tertulis berorientasi pada begriffsjurisprudenz.

Ada putusan sengketa ekonomi syariah yang menggunakan dasar hukum positif saja seperti KUHPerdata, Herzien Inlandsch Reglement (HIR), UU Peradilan Agama, UU Hak Tanggungan dan Hukum positif lainnya. Sebagai contoh pada putusan hakim Pengadilan Agama Tegal No. Perkara 0336/Pdt.G/2017/PA.Tg dimana dalam gugatannya perlawanan terhadap lelang yang dilakukan oleh bank syariah. Di dalam putusannya hakim menimbang bahwa perlawanan pelawan yang alamat domisilinya kabur dan tidak jelas sehingga perlawanannya tidak dapat diterima. Hakim menggunakan dasar pertimbangan hukum mengacu kepada Yurisprudensi Mahkamah Agung Nomor: 565 K/Sip/1973 tanggal 21 Agustus 1974 dan Putusan Mahkamah Agung RI Nomor: 582 K/Sip/1973 tanggal 18 Desember 1975. Selain itu dasar pertimbangan hakim yang lain mengacu pada UU Peradilan Agama, HIR, Peraturan Mahkamah Agung Nomor 02 Tahun 2009 tentang Biaya Proses Penyelesaian Perkara dan Pengelolaannya dan Peraturan Pemerintah Nomor 53 Tahun 2008 tentang Jenis dan Tarif PNBP. ${ }^{21}$

Putusan Pengadilan Agama Sragen Nomor Perkara 1/Pdt.G.S/2020/PA.Sr, dalam gugatan wanprestasi, dalam pertimbangan putusannya hanya berdasar pada fatwa Dewan Syariah Nasional MUI Nomor 17 Tahun 2000 tentang pemberian sanksi keterlambatan dan Peraturan Mahkamah Agung Nomor 2

\footnotetext{
20 Amran Suadi, Penyelesaian Sengketa Ekonomi Syariah dalam Teori dan Praktek, Kencana, Depok, 2017, hlm. 7.

${ }^{21}$ https:// putusan3.mahkamahagung.go.id/direktori/putusan/1956924e474969174433b7b384c4babe3html , diakses 25 Agustus 2020
} 
Tahun 2015 tentang Tata Cara Penyelesaian Gugatan Sederhana. Pertimbangan lainnya hakim hanya mencocokan antara bunyi akad dengan fakta persidangan.

Putusan Pengadilan Agama Jepara Nomor 512/Pdt.G/2020/PA.Jepr. mengenai gugatan wanprestasi akad murabahah wal Ijarah. Dalam putusanannya, dasar pertimbangan hukum yang digunakan hakim merujuk pada pasal-pasal dalam KUHPerdata dan hukum formilnya PERMA No. 1 Tahun 2016 dan HIR. Putusan pengadilan agama Cilacap Nomor 6379/Pdt.G/2019/PA.Cl, dasar pertimbangan hakim hanya menggunakan KUHPerdata dan KHES serta HIR. ${ }^{22}$

Banyak pula putusan hakim pengadilan agama menggunakan dasar pertimbahan hukum materiel yang bersumber dari hukum Islam. Sebagai contoh pada putusan pengadilan agama Purwodadi Nomor 5/Pdt.GS/2019/PA.Pw, yaitu perkara gugatan wanprestasi, hakim dalam pertimbangan hukum mengacu kepada Al Quran, Al-hadits, pendapat ahli fiqih, Fatwa DSN MUI, KHES dan hukum positifnya hanya UU Perkoperasian saja, karena yang diperiksa adalah lembaga keuangan dalam bentuk Koperasi Simpan Pinjam Pembiayaan Syariah. Serta menggunakan perundang-undangan positif sebagai hukum formilnya seperti UU Peradilan Agama, HIR, PERMA. ${ }^{23}$

Demikian pula putusan hakim pengadilan agama Ambarawa Nomor 0002/Pdt.G.S/2020/PA.Amb perkara gugatan wanprestasi akad pembiayaan Murabahah bil Wakalah antara nasabah dengan bank syariah. Dalam pertimbangan hukumnya, hakim pengadilan agama menggunakan dasar Al Quran surat Al Maidah ayat (1), Hadits Nabi Muhammad, Pasal 26 dan 28 ayat (1) KHES, Pasal 1320 KUHPerdata, Pasal 181 HIR ayat (1), Pasal 49 Undang-Undang Nomor 3 Tahun 2006 tentang perubahan Undang-Undang Nomor 7 Tahun 1989, yang telah diubah dengan perubahan kedua menjadi Undang-Undang Nomor 50 Tahun 2009 tentang Peradilan Agama, PERMA Nomor 14 Tahun 2016 tentang Tata Cara Penyelesaian Perkara Ekonomi Syariah jo PERMA Nomor 2 Tahun 2015 tentang Tata Cara Penyelesaian Gugatan Sederhana, PERMA Nomor 4 Tahun 
2019 tentang Perubahan atas Peratutan Mahkamah agung Nomor 2 Tahun 2015 tentang Tata Cara Penyelesaian Gugatan Sederhana. ${ }^{24}$

Dari berbagai putusan tersebut di atas, hakim pengadilan agama yang hanya melihat hukum tertulis saja dalam putusannya yaitu KUHPerdata dan hukum positif lainnya berorientasi pada aliran penemuan hukum legisme. Pada aliran hukum legisme, satu-satunya sumber hukum adalah undang-undang yang dianggap cukup jelas dan lengkap dan berisi semua jawaban terhadap semua persoalan hukum, sehingga hakim hanya berkewajiban untuk menerapkan peraturan hukum pada peristiwa konkritnya dengan bantuan metode penafsiran terutama penafsiran gramatikal. ${ }^{25}$ Meskipun secara prosedural, dalam perkara perdata hakim tidak boleh memutus melebihi apa yang dituntut para pihak. Dalam Pasal 178 ayat (2) dan (3) HIR larangan bagi hakim memutus perkara yang tidak dituntut dan mengabulkan lebih dari yang dituntut. Sementara tuntutan dalam perkara sengketa ekonomi syariah yang digugat adalah perkara wanprestasi atau perbuatan melawan hukum serta perlawanan sita jaminan. Seharusnya hakim dapat melakukan penemuan hukum atau berorientasi pada sudut pandang yang berbeda dari sekedar melihat tuntutan para pihak. Karena yang disengketakan adalah perjanjian yang dasarnya adalah akad syariah, seyogyanya hakim juga menggali prinsip-prinsip syariah yang dianut dalam hukum Islam. Hakim yang berorientasi pada penemuan hukum legisme tidak didukung oleh dasar filosofis Pancasila, karena nilai yang terkadung di dalam sila pertama, kedua dan kelima diderivasi ke dalam aliran penemuan hukum begriffsjurisprudenz, dimana dalam aliran penemuan hukum begriffsjurisprudenz lebih memberikan kebebasan kepada hakim. Hakim tidak hanya terikat pada bunyi undang-undang, tetapi dapat mengambil argumentasinya dari peraturanperaturan hukum yang tersirat dalam undang-undang. ${ }^{26}$

Akad setelah ditandatangai berlaku sebagai undang-undang bagi para pihak, karena akad bersumber dari hukum Islam, maka seyogyanya hakim juga harus menggali prinsip-prinsip yang terkandung di dalamnya. Pada dasarnya,

\footnotetext{
${ }^{24}$ Ibid

${ }^{25}$ Sudikno Mertokusumo, Penemuan Hukum..., Op. Cit., hlm. 195

${ }^{26}$ Ibid., hlm. 98
} 
prinsip-prinsip yang terkadung dalam ekonomi syariah bersumberkan dari nilainilai yang terkandung dari Al Qur'an dan Sunnah. Prinsip-prinsip tersebut sekaligus menjadi pembeda dengan ekonomi konvensional. ${ }^{27}$

Namun, ada pula putusan hakim pengadilan agama yang menyelesaikan sengketa ekonomi syariah dalam pertimbangan hukumnya menggunakan dalildalil yang berasal dari fatwa DSN, KHES dan dalil dalam Al Qur'an dan Hadits. Salah satu putusan tersebut dapat ditemui dalam perkara No. 5/Pdt.GS/2019/PA.Pwd. Meskipun gugatan tersebut adalah gugatan wanprestasi, hakim dalam mengadili menggunakan dasar selain dari hukum positif juga dari Al Qur'an, Hadits Nabi dan fatwa DSN MUI serta Kitab UndangUndang Hukum Ekonomi Syariah. Dalam hal ini hakim sudah menggali norma hukum selain yang ada di dalam hukum positif. Hakim tidak semata-mata hanya melihat hukum dari aturan yang tertulis saja tetapi juga harus melihat nilai yang ada, dalam hal ini karena akad yang disengketakan bersumber dari hukum Islam, maka hakim juga menggunakan sumber hukum Islam dalam menyelesaikannnya. Putusan hakim pengadilan agama Purwodadi tersebut sejalan dengan aliran penemuan hukum begriffsjurisprudenz.

Aliran penemuan hukum begriffsjurisprudenz inilah yang sejalan dengan Pancasila dan UU Kekuasaan Kehakima. Pasal 2 ayat (2) UU Kekuasaan Kehakiman disebutkan bahwa peradilan negara menegakkan dan menerapkan hukum dan keadilan berdasarkan Pancasila. Artinya bahwa hakim di dalam memutuskan suatu sengketa yang diajukan kepadanya tidak hanya untuk diputus berdasarkan hukum (peraturan belaka) tetapi juga keadilan. Meskipun perkara yang disengketakan adalah persoalan wanprestasi, namun hakim harus melihat wanprestasi tersebut terjadi dari perjanjian yang berdasarkan prinsip syariah. Hakim harus melihat akad syariah yang menimbulkan persengketaan dari sumber hukum terjadinya akad seperti fatwa DSN MUI, Fiqh Muamalah, KHES. Hakim perlu memperhatikan prinsip utama dalam menangani perkara ekonomi syariah di Pengadilan Agama. Adapun prinsip utama yang harus benarbenar dipahami dan diperhatikan dalam menangani perkara ekonomi syariah pada umumnya, bahwa dalam proses penyelesaian perkara tersebut sama sekali

${ }^{27}$ Amran Suadi, Penyelesaian Sengketa Ekonomi Syariah dalam Teori..., hlm. 5 
tidak boleh bertentangan dengan prinsip syariah. Hal ini jelas merupakan prinsip fundamental dalam menangani dan menyelesaikan perkara ekonomi syariah di Pengadilan Agama. ${ }^{28}$

Keadilan yang dikehendaki dalam UU Kekuasaan Kehakiman tentu saja tidak hanya keadilan formal yang mengacu pada peraturan yang tertulis saja, tetapi juga melihat keadilan substansial yaitu hukum yang tidak tertulis. Meskipun prinsip syariah sebagaimana yang dimaksud dalam UU Perbankan Syariah berlum secara formal diundangkan dalam hukum positif, hakim dapat menggali nilai-nilai yang ada, dalam sengeta ekonomi syariah maka hakim wajib menggali nilai yang terkadung dalam ajaran agama Islam. Hal ini sejalan dengan Pasal 5 ayat (1) UU Kekuasaan Kehakiman yaitu, hakim dan hakim konstitusi wajib menggali dan mengikuti serta memahami nilai-nilai hukum dan rasa keadilan yang hidup di masyarakat.

Hakim pengadilan agama di dalam memeriksa dan memutus sengketa perbankan syariah semestinya mengacu kepada peraturan perundang-undangan yang berlaku yang terkait dengan perbankan syariah. Sehingga jika di dalam proses persidangan terdapat akad atau bahkan peraturan perundang-undangan yang bertentangan dengan prinsip syariah maka majelis hakim harus berani untuk melakukan penemuan hukum dengan menggali nilai-nilai yang hidup di dalam masyarakat. Nilai-nilai yang dimaksudkan dalam penyelesaian perbankan syariah ini adalah prinsip-prinsip syariah yang bersumber dari hukum Islam. Dengan demikian maka para pihak akan mendapatkan perlindungan hak spriritual pada penyelesaian sengketa perbankan syariah baik dari kepentingan nasabah maupun bank syariah. ${ }^{29}$

Menurut aliran begriffsjurisprudenz, hakim pengadilan agama dapat melihat pada substansi akad, jika dinilai bahwa sumber sengketa berawal dari akad yang kurang adil atau dianggap bertentangan dengan prinsip syariah. Dalam menyusun akad syariah yang standar perlu melibatkan berbagai pihak terutama masyarakat, industri perbankan, pembentuk UU, Bank Indonesia, ikatan notaris,

28 Amran Suadi, Penyelesaian Sengketa Ekonomi Syariah dalam Teori..., hlm. 17

29 Ro'fah Setyowati, Perlindungan 'Hak Spiritual' Dalam Penyelesaian Sengketa Perbankan Syariah: Praktik Di Malaysia Dan Indonesia, dalam Jurnal Share, Volume 5, Number 2, July - December 2016, hlm. 142. 
Otoritas Jasa Keuangan, sehingga akad yang dihasilkan tidak hanya berdasarkan perjanjian yang biasanya berupa perjanjian baku yang dibuat oleh lembaga keuangan. Standarisasi akad diharapkan akan memberikan kenyamanan para pihak dan kepastian hukum serta tidak menimbulkan kebingungan di dalam masyarakat serta terhindar dari gharar, maisir dan riba sehingga transaksi syariah terwujud dengan baik dan aman tanpa menimbulkan sengketa. ${ }^{30}$

Ekonomi syariah dilakukan berdasarkan syariat Islam, maka sudah seharusnya pengadilan agama diberikan kepercayaan berupa kewenangan absolut untuk menyelesaikan sengketa ekonomi syariah yang dilakukan oleh orang yang beragama Islam atau pihak yang secara sukarela menundukkan diri dengan hukum Islam. Dengan demikian hakim pengadilan agama di dalam menyelesaikan sengketa ekonomi syariah harus memahani norma-norma hukum ekonomi syariah, mampu menerapkan hukum sebagai instrumen mengadili, mampu melakukan penemuan hukum untuk memperoleh keadilan. ${ }^{31}$ Dasar hukum yang dipergunakan dalam menyelesaikan tidak hanya mengacu kepada hukum yang tertulis saja akan tetapi juga menggali prinsip-prinsip syariah untuk dapat memberikan keputusan yang adil bagi para pihak.

\section{Penutup}

Berdasarkan uraian pada pembahasan di atas, ada beberapa simpulan sebagai berikut: Pertama, penyelesaian sengketa ekonomi syariah memiliki landasan filosofis dari nilai-nilai Pancasila khususnya sila pertama, kedua dan kelima. Berdasarkan penjabaran sila-sila dalam Pancasila diderivasi dalam aliran penemuan hukum yaitu begriffsjurisprudenz dan interessjurisprudenz. Kedua, ada dua ragam orientasi hakim pengadilan agama dalam memutuskan sengketa ekonomi syariah yaitu berorientasi legisme dan berorientasi begriffsjurisprudenz. Dari berbagai putusan yang telah berkekuatan hukum masih ada putusan hakim pengadilan agama yang berorientasi pada legisme, yaitu memutuskan sengketa berdasarkan hukum positif saja meskipun sengketanya adalah sengketa ekonomi

${ }^{30}$ Dewi Nurul Musjtari, Pembaharuan Hukum dalam Bidang Hukum Ekonomi Syariah, dalam Kanun Jurnal Ilmu Hukum, Vol. 19, Nomor 2 (Agustus 2017), hlm. 341

31 Fatchurohman, Wilda Nugraismia, Tri Wahyuni, Fahmi Medias, Penyelesaian Sengketa Nasabah Wanprestasi Ekonomi Syariah Di Pengadilan Agama Magelang dalam Indonesian Journal of Islamic Literature and Muslim Society, Vol. 3, No. 1, 2018, hlm. 99 
syariah. Banyak pula putusan hakim pengadilan agama yang berorentasi pada begriffsjurisprudenz, yaitu hakim sudah menggali nilai yang ada yang hidup dalam masyarakat, dalam hal ini hakim menggunakan dasar hukum Islam yaitu $\mathrm{Al}$ Quran dan Hadits serta Fatwa DSN MUI dan KHES dalam putusannya selain menggunakan KUHPerdata (hukum positif).

\section{Daftar Pustaka}

\section{Buku}

Kaelan, Filsafat Pancasila Pandangan Hidup Bangsa Indonesia, Paradigma, Yogyakarta, 2002.

Karjoko, Lego, Pembadanan Asas Fungsi Sosial Hak Guna Usaha dalam Pengaaturan Perkebunan yang Mensejahterakan rakyat, Disertasi, Pascasarjana UNS, Surakarta, 2017

Kartika Rahayu, Muji, Sengketa Mazhab Hukum, Sintesis Berbagai Mazhab dalam Pemikiran Hukum, Penerbit Buku Kompas, Jakarta, 2018.

Mertokusumo, Sudikno, Penemuan Hukum Suatu Pengantar, Lyberti, Yogyakarta, 2009.

Mukhlas, Oyo S., Dual Banking System \& Penyelesaian Sengekta Ekonomi Syariah, Refika Aditama, Bandung, 2019.

Nur Rosidah, Zaidah, dkk, Aspek Keadilan Penyelesaian Sengketa Bisnis Syariah Melalui Pengadilan Agama, LP2M IAIN Surakarta, Surakarta, 2016.

Sulistiyono, Adi, Mengembangkan Paradigma Non-Litigasi di Indonesia, Sebelas Maret University Press, Surakarta, 2006.

Suadi, Amran, Penyelesaian Sengketa Ekonomi Syariah dalam Teori dan Praktek, Kencana, Depok, 2017.

- Penyelesaian Sengketa Ekonomi Syariah Penemuan dan Kaidah Hukum, Prenada media Group, Jakarta, 2018.

\section{Jurnal}

Arief Budiman, Achmad, Penemuan Hukum Dalam Putusan Mahkamah Agung Dan Relevansinya Bagi Pengembangan Hukum Islam Indonesia, AlAhkam Jurnal Pemikiran Hukum Islam, Volume 24, Nomor 1, April 2014.

Fatchurohman, Wilda Nugraismia, Tri Wahyuni, Fahmi Medias, Penyelesaian Sengketa Nasabah Wanprestasi Ekonomi Syariah Di Pengadilan Agama Magelang dalam Indonesian Journal of Islamic Literature and Muslim Society, Vol. 3, No. 1, 2018.

Hariyanto, Erie, Penyelesaian Sengketa Ekonomi Syariah Di Indonesia, dalam Jurnal Iqtish al-Ihkâmadia, Vol 1. Nomor 1, 1 Juni 2014. 
Nurul Musjtari, Dewi , Pembaharuan Hukum dalam Bidang Hukum Ekonomi Syariah, dalam Kanun Jurnal Ilmu Hukum, Vol. 19, Nomor 2 Agustus 2017.

Setyowati, Ro'fah, Perlindungan 'Hak Spiritual' Dalam Penyelesaian Sengketa Perbankan Syariah: Praktik Di Malaysia Dan Indonesia, dalam Jurnal Share, Volume 5, Number 2, July - December 2016.

Setyowati, Ro'fah, Indah Purbasari, Encik Muhammad Fauzan, Consumers Spiritual Rights in the Islamic Banking Dispute Out of Court Settlement in Indonesia dalam Journal of Social Studies Education Research, 2018:9 (4).

\section{Internet}

Rasyid, Abdul, Perkembangan Lembaga Perbankan Dan Keuangan Syariah Di Indonesia, https://business-law.binus.ac.id/2018/07/03/perkembanganlembaga-perbankan-dan-keuangan-syariah-di-indonesia/, diakses 25 Juni 2020.

https://www.hestanto.web.id/lembaga-keuangan-syariah-lks/, diakses 25 Agustus 2020.

https://putusan3.mahkamahagung.go.id/direktori/kategori/jenis/ekonomisyari-ah-1.html, diakses 25 Juni 2020.

https://www.ojk.go.id/id/kanal/syariah/tentang-syariah/Pages/PBS-danKelembagaan.aspx, diakses 25 Agustus 2020. 